\title{
The Delicate Order of Liberalism: Resentment Politics and the Public Trust
}

\author{
Scott G. Nelson, Virginia Tech \\ Joel T. Shelton, Elon University
}

In response to the advance of right-wing populism in many Western democracies, political economists have sought explanations for political disaffection in the socioeconomic dislocations wrought by globalization, deindustrialization, and automation. Distrust of institutions and elites has been identified as a consequence of open markets and neoliberal governance. While affirming the public trust as a cornerstone of liberal democracy, this article directs analysis of the contemporary condition to a broader set of uniquely psychosocial and cultural dynamics. We identify sentiments ranging from disillusion to defiance that are now fueling a runaway politics narrowly defined around race, ethnicity, and national identity. We examine the stakes of eroding public trust in historical and theoretical perspective through an analysis of key works of Karl Polanyi, John Maynard Keynes, and E. H. Carr. Drawing parallels to their assessments of the interwar period, we argue that today's resentment politics is not singularly the product of economic hardship or even institutional failure, but emerges also from a breakdown of the social and cultural ties that underpin liberalisma "delicate order" built in part on sublimated psychosocial understandings of agency and community. Democracy again hangs in the balance.

Keywords: political economy, public trust, Carr, Keynes, Polanyi, liberalism, resentment politics

Where the arrogance of intellect mates with spiritual antiquatedness and bondage, there the Devil is.

-Thomas Mann ${ }^{1}$

The authors contributed equally to this article. An early version was presented at the British International Studies Association Annual Conference, Bath, England, in June 2018. We thank our fellow panelists for their incisive comments. A later version was presented before the Political Economy Working Group at Virginia Tech in April 2019, and we thank Mauro Caraccioli, Bikrum Gill, and Besnik Pula for their helpful suggestions. We are also grateful for guidance we received at various stages from the anonymous reviewers, as well as from Larry Berlin, Paul Bowles, Ian Bruff, Timothy W. Luke, Luke Plotica, John T. Rowntree, Mark R. Weaver, and Edward Weisband.

1. Thomas Mann, cited in Thomas Mann: Life as a Work of Art, H. Kurzke (Princeton: Princeton University Press, 2002), 484.

Published online July 15, 2021.

Polity, volume 53, number 4, October 2021.

(C) 2021 Northeastern Political Science Association. All rights reserved. Published by The University of Chicago Press for the Northeastern Political Science Association. https://doi.org/10.1086/715583 


\section{Introduction}

7 he rising tide of a well-organized far-right politics in many European coun1 tries and the United States over the past several years has aroused interest among political economists in the economic, social, and cultural fault lines that have appeared in Western democracies. These fault lines, some commentators suggest, are in part the result of pressures deriving from global systems of production and investment in the second great period of globalization. ${ }^{2}$ The electoral appeal of illiberal populists in many countries points to broadly similar social and cultural dynamics that seem to be fueling economic nationalism and are galvanizing near majorities in undisguised displays of racism, xenophobia, and nativism. As the "political advance of an ethos of cultural revenge"3 appears more deeply entrenched in many countries, political economists of the center-left have framed illiberal politics as a reaction to the harmful effects of "unmanaged" or "hyper" globalization. ${ }^{4}$ These scholars, including Dani Rodrik, ${ }^{5}$ Joseph Stiglitz, ${ }^{6}$ and Robert Reich, ${ }^{7}$ have garnered public attention by extending critiques of globalization that were originally developed in the mid-1990s.

Although we are broadly sympathetic to a great number of critiques that position globalization as a contributing factor behind today's right-wing populism-especially those critiques that highlight the toxic effects of rising inequality within economies $^{8}$ - we find that singling out globalization as a primary cause of the turn to illiberal politics misses the mark. Too often, political economists have difficulty

2. Jeffry Frieden, Global Capitalism: Its Fall and Rise in the Twentieth Century (New York: W.W. Norton, 2007).

3. William E. Connolly, Capitalism and Christianity, American Style (Durham, NC: Duke University Press, 2008), xii.

4. Dani Rodrik, The Globalization Paradox: Democracy and the Future of the World Economy (New York: W.W. Norton, 2011).

5. Dani Rodrik, Straight Talk on Trade: Ideas for a Sane World Economy (Princeton: Princeton University Press, 2018).

6. Joseph Stiglitz, Globalization and Its Discontents Revisited: Anti-Globalization in the era of Trump (New York: W.W. Norton, 2017).

7. Robert B. Reich, Saving Capitalism: For the Many, Not the Few (New York: Knopf, 2015); and Robert B. Reich, The Common Good (New York: Vintage, 2018).

8. Several important titles we would note here are Joseph Stiglitz, The Price of Inequality (New York: W.W. Norton, 2013); James Galbraith, Inequality and Instability (Oxford: Oxford University Press, 2013); Thomas Piketty, Capital in the Twenty-first Century (Cambridge: Harvard University Press, 2017); Branko Milanovic, Global Inequality: A New Approach for the Age of Globalization (Cambridge: Harvard University Press, 2016); and Francois Bourguignon, The Globalization of Inequality (Princeton: Princeton University Press, 2017). 
moving from a description of emerging political and cultural divisions to an analysis of underlying psychological and social dynamics that are working in tandem with economic forces. These dynamics reflect a host of social and cultural sentiments and feelings registered by growing numbers of people who perceive themselves to be "left behind" by societies in a state of rapid structural transformation. A deeper inquiry into the politics of the contemporary social and cultural conditions of many Western democracies thus requires confronting several challenges that political economists rarely address (for reasons to be discussed). Among these challenges is the cultural power of resentment that has emerged out of accumulating tensions within liberal democracies, tensions that have been building for decades as nations have become more diverse, as the world economy has become more integrated, and as societies have failed to align domestic governance priorities in turn.

Our aim in this article is to lay the groundwork for a type of political-economic analysis that can account for the emergence of psychosocial and cultural forces in relation to new economic forces and existing political priorities, some of them global in scope, although many of them regional and national. We do so by revisiting accounts of the politics of another period for insights into the interplay of a broad number of social and cultural relations fueling a runaway illiberal politics today, with the objective to sharpen critics' understanding of a series of critical weaknesses in liberalism. We begin with some preliminaries about the disciplinary shortcomings of political economy in relation to the psychosocial and cultural dynamics that we think scholars must now consider alongside the economic forces of globalization. We then frame our analysis of these dynamics through a consideration of a much different period of political and economic upheaval, interwar Europe, engaging the theoretical examinations of the intellectual climate of the period advanced by Karl Polanyi, John Maynard Keynes, and E. H. Carr. Theorists of the interwar period offer one of the most important case studies we have of the social dislocation and psychological strain that follow an economic system organized by "self-adjusting" markets; their examinations provide a critical accounting of the ways in which social forces and cultural conditions disrupt the political prerequisites of institutional and non-institutional adaptation and renewal, ultimately disturbing the delicate and unstable conditions of liberalism. Moreover, their analyses confronted the emerging political stakes that societies courted, stakes that involved the social strains of rapid economic change and a compounding of dangers that shattered the public trust, leading to a dangerous deadlock of political interests. This deadlock was one in which emotional reactions-the accumulation of sentiments of disaffection, resentment, and rage-culminated in a politics that proved fertile ground for revolutionary upheaval and war. 
Political economists must now expand their optics to better grapple with the unique configuration of forces-including the decline in trust that people of diverse backgrounds and stations should pursue common political ends-again threatening what Keynes called the "delicate organization" of liberalism. For Keynes, this organization depends on several interpenetrating elements-among them, social, cultural, and psychological sentiments that may appear relatively fixed and incidental to political-economic life until they come undone. ${ }^{9}$ This often-long process of undoing is what interests us here.

\section{The Pathologies of Economism}

To what extent is the emergence of populism in Western countries a result of structural changes associated with national governance in the face of emerging strains of political and economic liberalism, rather than (exclusively) a reaction to structural problems afflicting the world economy? It could be argued that political economists who focus on economic openness and market integration as the primary driver of populism still display an economism that, in the words of one commentator, constitutes nothing less than a "social pathology of advanced capitalist society." 10 The prioritization of the economic over the political, the social, and the cultural-as if each were singular, coherent, and well bounded-has meant that political economists have too infrequently analyzed underlying sentiments that reflect a host of social and cultural experiences; nor have they investigated the relation of these sentiments to ongoing economic transformations at the domestic and international levels. Indeed, cultural tensions and what we term the psychosocial dimensions of today's resentment politics are too often positioned as secondary effects of economic forces, rather than as social dynamics with a diverse array of animating and mutually reinforcing mechanisms. These dynamics operate in relation to global dynamics of production and exchange but cannot be reduced to the acute symptoms of unmanaged or deregulated globalization as such.

Economism is a hindrance to the careful analysis of a complex interplay of forces that are difficult to disaggregate. This is particularly in evidence in the American context where various feelings, from disillusionment and resignation to resentment and rage, have fomented across socioeconomic strata. In the context of new registers of political affect, new economic sentiments have become barometers of

9. John Maynard Keynes, The Economic Consequences of the Peace (New York: Harcourt, Brace and Howe, 1920), 15.

10. Richard K. Ashley, "Three Modes of Economism," International Studies Quarterly 27 (1983): 492. 
revenge as well as resilience, and reactionary populists are once again proving skilled in persuading people that unstoppable global forces threaten their ways of life and livelihood, and, moreover, that particular groups represent especial threats to a presumed cultural, national, or ethnic integrity. More than presenting analytical difficulties, however, economism faces a much more serious charge. While few dispute the importance today of economic factors relative to a great many social and political outcomes, "heightening economic demands yield the greater rationalization of the state and diminishing political latitude, with a result that the world is fast approaching a modern and very dangerous version of Hobbes's geometric vision of international politics."11 The risk of rationalization is that the given order is naturalized and universalized as the only possible order, "an unsurpassed condition of necessity." 12 The "pathological tendency" of economism thereby renders as "idealistic" "all practice that would ignore or deny this logic."13

As a result of this economistic tendency, political economists concerned with social dislocation privilege policy over the task of constituting a new politics at a time when the causes of the current crisis are still not well defined, and when new models of political-economic reform still do not receive attention. Critics of globalization who come from the field of economics tend to ignore how the political groundwork necessary for any shared articulation of international and domestic policy has itself been compromised. Some political economists may be inclined to theorize a common political sensibility, one that can be conceived in terms of the common good or the public trust, but they generally lack the theoretical resources to deliver such an analysis. As we define it, the public trust is perhaps the most essential element of democratic life; it is a necessary prerequisite for the pursuit of collective ends and shared purposes in an economic and political system ostensibly concerned to widen economic and political opportunity. ${ }^{14}$ The public trust sustains reciprocal bonds of obligation and dependence, supports shared civic convictions, and underwrites confidence in collective endeavors in the context of individual and group differences. Such a form of political trust serves to invest collective energies in a shared enterprise. ${ }^{15}$

11. Ashley, "Three Modes," 490.

12. Ibid., 490.

13. Ibid., 491.

14. Wendy Brown, Undoing the Demos: Neoliberalism's Stealth Revolution (New York: Zone Books, 2015).

15. See Scott G. Nelson and Joel T. Shelton, "The Public Purpose of Political Economy," New Political Science 41 (2019), 400-422. 
In recent years, some critics of globalization have begun to acknowledge the sources of anger, mistrust, and a range of credibility issues at work in contemporary politics. ${ }^{16}$ However, these analyses usually display limitations that derive from an economistic bias and the analytical prioritization of policy. Rodrik, for example, works to "imagine a better balance between markets and their supporting institutions at the global level"; ${ }^{17}$ similarly, a mainstay for Stiglitz (who has acknowledged his great debt to Karl Polanyi) are accounts that prioritize rules and institutions ${ }^{18}$ over attitudes and especially over strongly felt opinions that so quickly reach fever pitch in today's networked media environments. The prevailing diagnosis is clear: a change of policy will bring a reduction of pathos. Thus, it is not surprising to find so many political economists still devoted to the analysis of a rule-based system of globalization, from financial architectures to institutional norms and policymaking outcomes.

Among the center-left critics of runaway globalization, Reich stands out for his attention to the "serious depletion [of] the pool of trust on which our society depends," ${ }^{19}$ what for him is a major impediment to a politics oriented to the "common good." Reich argues that distrustful citizens are more likely to turn to "demagogues" who "can use the anger and fear accompanying disruptive change to turn people against one another rather than address the traumas that made them angry in the first place. ${ }^{20} \mathrm{He}$ concludes that these dynamics all but destroy the prospects for policy remediation. ${ }^{21}$ As political community is rearticulated along narrow, exclusionary, and ultimately illiberal lines, ${ }^{22}$ institutions of politics fracture in ways that render policy discussions essentially fruitless exercises.

The origins of the "dangerous sentiments" 23 identified by Reich, however, run much deeper than what he presents as a "whatever-it-takes-to-win politics" and a "whatever-it-takes-to-maximize profits" political economy. ${ }^{24}$ Attending theoretically

16. See Rodrik, Straight Talk on Trade, xi, 171; and Stiglitz, Globalization and Its Discontents Revisited, 51, 53.

17. Rodrik, The Globalization Paradox, 235.

18. Stiglitz, Globalization and Its Discontents Revisited, 75-76.

19. Reich, The Common Good, 111.

20. Ibid., 28.

21. Ibid., 111.

22. See Sheldon S. Wolin, Politics and Vision: Continuity and Innovation in Western Political Thought, expanded edition (Princeton: Princeton University Press, 2004). Another valuable study directed at these concerns is Vincent Ostrom, The Meaning of Democracy and the Vulnerability of Democracy: A Response to Tocqueville's Challenge (Ann Arbor: University of Michigan Press, 1997).

23. Reich, The Common Good, 134.

24. Ibid., 90 . 
to the deep and difficult wells of a range of powerful human sentiments-among them, diminished expectations, antipathy, growing distrust, hatred, and rage-requires a different kind of analysis, at once comparative and historical. On the basis of such an analysis the political-economic structure of capitalism can be seen as facilitating a whole series of forces that liberal democracies have, tragically, proved incapable of directing to serve the public purpose.

\section{The Delicate Order of Liberalism}

It is possible to view the disturbances that have accompanied the second age of globalization as a return to the problems of the first-the forgetting of hard-won lessons about the need for nation-states to protect their citizens from the vicissitudes of global dynamics. Yet in crucial respects Karl Polanyi's analysis of the destabilizing effects of the "stark utopia" implied by the "self-adjusting market," 25 J. M. Keynes's account of the deception and ideological pretext of laissez-faire, ${ }^{26}$ and E. H. Carr's assessment of the "bitter mockery" unleashed by the collapse of the "harmony of interests" 27 are quite distinct from the analysis of contemporary political economy. In contrast to much of this work, Polanyi, Keynes, and Carr's analyses were not aimed at indicting the excesses of unmanaged economic integration as such. The principal forces preoccupying these thinkers were the essential theoretical and heuristic limits of liberalism, the dominant metaphysics undergirding the basic organization of state and society. Here liberalism is understood not merely as an "organizing principle"28 for economic and social relations, but more fundamentally as a way of conceiving the self in relation to the community and the private in relation to collective concern. When the relationship between individual and community becomes a matter of contestation, liberalism can be a catalyst for social and cultural disruption.

There is no better starting point for this analysis than Polanyi's The Great Transformation, justly one of the most celebrated accounts of the "human and economic, physical and moral" dislocations that provoked such rapid changes in politicaleconomic life of the late nineteenth and early twentieth centuries. ${ }^{29}$ Among the most original and lasting contributions of Polanyi's study is his analysis of the early

25. Karl Polanyi, The Great Transformation: The Political and Economic Origins of Our Time (Boston: Beacon Press, 2001 [1944]), 3.

26. Keynes, The Economic Consequences, 19.

27. E. H. Carr, The Twenty Years' Crisis (New York: Perennial, 2001 [1939]), 81.

28. Polanyi, The Great Transformation, 155.

29. Polanyi, The Great Transformation, 39. 
twentieth-century upheavals in terms of the consolidation of a liberal metaphysics that encompassed a broad array of embedded, quasi-religious sentiments-political, social, and economic-that constituted political experience and in turn were reflected and manifested in people's expectations and fears. In Polanyi's analysis, the belief system that undergirded the liberal order - a "veritable faith in man's secular salvation through a self-regulating market"30 - was most remarkable for what it overlooked: namely, the ways in which societies organized on the basis of the principle of economic liberalism were built on a most unstable foundation.

Polanyi's own commitments were grounded in a perspective that situated market relations within a general matrix of social progress. His analysis was in large part designed to show that the self-regulating market system was but a myth: capitalist relations of production and exchange did not emerge naturally from some innate, pre-political propensity to barter and trade. Motives of gain that were channeled through the market system required a vast extension of bureaucratic control and centralization to undo traditional, institutionalized relations of exchange organized by kinship, communal obligations, and tradition-bound hierarchies. ${ }^{31}$ For Polanyi, "laissez-faire was not a method to achieve a thing, it was a thing to be achieved." 32 Governments, therefore, had a critical role to play in dis-embedding the market mechanism from the "arbitrary" constraints of society, including those that come from the political realm itself.

Of course, there was more to laissez-faire than technical mechanisms and claims about their superiority over political directions and social controls. Because the ideal of the self-regulating market can never be fully realized, a political enactment must be brought into effect, a theatrical performance that is capable of giving people over to the idea of the self-regulating market's naturalness, its necessity. Yet, this performance would inevitably break down under the forces of geopolitical destruction and the corresponding disillusion and distrust unleashed by the market mechanism.

Polanyi argued that when elevated to a status tantamount to a metaphysics, as the organizing principle ${ }^{33}$ of political-economic life, the self-regulating market would "annihilate all organic forms of existence," replacing them with "a different type of organization, an atomistic and individualistic one." ${ }^{34}$ His great worry was

\footnotetext{
30. Ibid., 141 .

31. Ibid., 56-57.

32. Ibid., 145 .

33. Ibid., 155.

34. Ibid., 171.
} 
that in order to maintain unified and predictable markets for raw-material inputs in industrial production, ${ }^{35}$ the self-regulating market system would liquidate all "noncontractual organizations of kinship, neighborhood, profession, and creed . . since they claimed the allegiance of the individual and thus restrained his freedom." ${ }^{\text {"36 }}$ Damage that was inflicted upon societies, Polanyi suggested, stretched across a "broad range of vital social interests," 37 all of them bearing on matters of status. The harms visited upon communities would provoke an inevitable countermovement against economic liberalism - a movement for social protection that took a "great variety of forms," ${ }^{38}$ few of them benign. Polanyi termed the actions of these contending social forces the "double movement."39

Polanyi's analysis of the basic limits of the liberal metaphysic has overshadowed parallel accounts offered by his contemporaries, theorists who shared Polanyi's concern with the harmful social effects of free-market economic orthodoxy. J. M. Keynes and E. H. Carr derived similar lessons from their own experiences with the slow collapse of the political and economic condition of Europe in the period 1870-1914. Keynes's work in particular reflects an abiding interest in the peculiarity and instability of the central tenets of political economy-the "unusual, unstable, complicated, unreliable, temporary nature" 40 of economic organization, the fleeting and episodic quality of economic progress, ${ }^{41}$ and the "psychology of society" ${ }^{42}$ that was all-too-evident in periods of abundance as well as scarcity. In the opening pages of The Economic Consequences of the Peace, for example, Keynes described the singular experience of living through the "extraordinary episode" 43 of the prewar years in Europe, during which time a sense of the normalcy, certainty, and permanence of international economic harmony prevailed-at least for those occupying an elevated social position. Only with the benefit of hindsight was it understood that this "happy age" ${ }^{44}$ was sustained by a "delicate organization" 45 of volatile elements-among them an extended period of "order, security, and uniformity" in
35. Ibid., 155.
36. Ibid., 171 .
37. Ibid., 151.
38. Ibid., 151.
39. Ibid., 138.
40. Keynes, The Economic Consequences, 3.
41. Ibid., 11 .
42. Ibid., 18 .
43. Ibid., 10 .
44. Ibid., 10 .
45. Ibid., 15 . 
Europe ${ }^{46}$ Europe's imperial "claim on the resources of the new world," ${ }^{\prime 7}$ and the rapid expansion of German industry, which stimulated regional trade and capital investment. ${ }^{48}$ Beyond geopolitical and economic factors, Keynes also cited "general dispositions common to the whole of Europe" as a critical feature of an emerging status-quo. $^{49}$

Keynes's interest in the political-economic effects of human psychology is well known, particularly his analysis of the so-called animal spirits that drive investor and consumer behaviors. Less remarked upon is the way that Keynes positions "unstable psychological conditions" 50 relative to a more fundamental illusion that sustained the popularity of the laissez-faire doctrine in the decades before the First World War - the illusion of an inevitable harmony achieved by international liberalism. Transformed from economic doctrine to deeply held belief, this illusion achieves a metaphysical status that Polanyi would later identify as a creed, one of the great obstacles to government involvement in the economy, especially relative to efforts to dis-embed the economy from society.

For Keynes, the origins of laissez-faire liberalism were evident in "the philosophizing of the eighteenth century and the decay of revealed religion.." ${ }^{\prime 1}$ Its primary achievement was to orient political, moral-ethical, and economic life to the rights and utility of individuals, and to furnish "a satisfactory intellectual foundation to the rights of property and to the liberty of the individual in possession to do what he liked with himself and with his own." 52 The resulting edifice is a "harmony of opposites" - a "miraculous union" reconciling individual and the general interest, thereby securing "the idea of a divine harmony between private advantage and the public good."53 The miraculous synthesis became deeply entrenched in the minds of the elite thanks to its claim to rationalism. Keynes observed, "to the philosophical doctrine that government has no right to interfere, and the divine that it has no need to interfere, there is added a scientific proof that its interference is inexpedient." ${ }^{54}$
46. Ibid., 16 .
47. Ibid., 25 .
48. Ibid., 16-17.
49. Ibid., 18 .
50. Ibid., 22.
51. John Maynard Keynes, "The End of Laissez-faire," in The Essential Keynes, ed. Robert Skidelsky (London: Penguin, 2015), 45.
52. Ibid., 40 .
53. Ibid., 42 .
54. Ibid., 42 
Keynes held economists accountable for furnishing laissez-faire with scientific credentials in the consolidation of the discipline, but he insisted that "popularisers" and "vulgarisers" were mainly to blame for the doctrine's power, ${ }^{55}$ which prevailed despite the best efforts of "the guarded and undogmatic attitude of the best economists." 56 The "lasting hold" of the doctrine was best explained by "the needs and wishes of the business world of the day." ${ }^{57}$ Laissez-faire's status was derived from its eminent use as a "pretext by which the practical man could solve the contradiction between egoism and socialism," for free trade" ${ }^{\text {"59 }}$ could gain traction as the doctrine's "most fervent expression." 60

It was during the heady years of the first great period of globalization that the "deep-seated melancholy" that infused the work of early political economists was replaced by "false hopes," 61 according to Keynes. The hopes were false because the "metaphysical or general principles"62 upon which laissez-faire was founded were, in Keynes's mind, simply not true:

It is not true that individuals possess a prescriptive 'natural liberty' in their economic activities. There is no 'compact' conferring perpetual rights on those who Have or on those who Acquire. The world is not so governed from above that private and social interest always coincide. It is not so managed here below that in practice they coincide. It is not a correct deduction from the principles of economics that enlightened self-interest always operates in the public interest. Nor is it true that self-interest generally is enlightened; more often individuals acting separately to promote their own ends are too ignorant or too weak to attain even these. Experience does not show that individuals, when they make up a social unit, are always less clear-sighted than when they act separately. ${ }^{63}$

Against these illusions pressed a stubborn and unrelenting reality: what Keynes called the "economic Eldorado" 64 of the pre-war decades was sustained by enormous inequalities in the distribution of wealth-inequalities that made possible
55. Ibid., 45 .
56. Ibid., 50 .
57. Ibid., 53 .
58. Ibid., 45 .
59. Ibid., 47 .
60. Ibid., 46
61. Keynes, The Economic Consequences, 10.
62. Keynes, "The End of Laissez-faire," 55.
63. Keynes, "The End of Laissez-faire," 55.
64. Keynes, The Economic Consequences, 10. 
those vast accumulations of fixed wealth and of capital improvements which distinguished that age from all others. ${ }^{65}$ For Keynes, the economic life of Europe in his own time was based on "a double bluff of deception"66 that depended upon the laboring classes, whether "from ignorance or powerlessness, or were compelled, persuaded or cajoled by custom, convention, authority, and the well-established order of Society into accepting, a situation in which they could call their own very little of the cake that they and Nature and the capitalists were co-operating to produce." ${ }^{67}$ At the same time, the capitalist, "theoretically free to consume" the best part of the cake, ${ }^{68}$ must commit to the duty of saving and investment. In Keynes's analysis, the great dislocations of the First World War brought a violent end to these "accumulative habits" 69 and to the commonplace assumptions of laissezfaire. With the onset of crisis, the "bluff is discovered": "the laboring classes may be no longer willing to forego so largely, and the capitalist classes, no longer confident in the future, may seek to enjoy more fully their liberties of consumption so long as they last, and thus precipitate the hour of their confiscation." ${ }^{\prime 0}$

Keynes's suspicions about the ideological labor performed by laissez-faire were also reflected in E. H. Carr's account of the central conceits of early twentiethcentury liberalism. Carr possessed a keen understanding of the unacknowledged power relations coursing beneath the surface of liberal society. Echoing Keynes's account of laissez-faire as a "harmony of opposites,"71 Carr positioned the harmony of interests as a "Utopian synthesis" which demands "that the highest interest of the individual and the highest interest of the community naturally coincide." ${ }^{22}$ Carr was under no illusion that economic policy makers of the interwar period actually practiced such a doctrine. He called attention to the "extraordinary divergence" between the theories of experts and the realities of economic nationalism so characteristic of the interwar years. ${ }^{73}$ More to the point, the lasting power of the laissezfaire doctrine for Carr was to be found not in the realm of economic policy, but in the way that the doctrine provided cover for the growing inequalities of the period leading up to the First World War, concealing the particular economic interests

65. Ibid., 18-19.

66. Ibid., 19 .

67. Ibid., 19 .

68. Ibid., 20.

69. Ibid., 22.

70. Ibid., 22.

71. Keynes, "The End of Laissez-faire," 42.

72. Carr, The Twenty Years' Crisis, 42.

73. Ibid., 55 . 
of "a prosperous and privileged class" behind claims of universalism and solidarity. ${ }^{74}$ While the falsehood of such a doctrine may be evident to the factory worker organizing for better pay and working conditions, Carr argued that the social function of laissez-faire was concealed most of all from its beneficiaries, who are often the most "sincerely convinced" of its adherents. ${ }^{75}$ "The doctrine of the harmony of interests thus serves as an ingenious moral device, invoked, in perfect sincerity, by privileged groups in order to justify and maintain their dominant position. ${ }^{376} \mathrm{Carr}$ understood that the "sincerely convinced" are generally the least likely to give ground; as the disharmony of interests became more and more evident, the appeals of the privileged to law and morality would only exacerbate the frustrations of the disaffected, who would set out "to create a new harmony by artificial means."77

\section{The Decay of the Public Trust}

Then as now, the fragility of the liberal metaphysic and its dependence on unshakeable beliefs, unstable myths, and unachievable dreams sets up an inevitable reckoning-though not merely the economic reckoning that is the focus of so much analysis in political economy today. What is also of great import, particularly to Keynes and Carr, is the deep attachment of individuals to evident falsehoods, and the psychosocial dynamics that accompany the collapse of the aspirations embodied in those falsehoods. Sustained by an "educational machine,"78 fictions, illusions, and feelings are the unsteady foundation of an optimistic vision of social harmony effected through the so-called "free" market. Shared dispositions and attachments upheld the delicate organization of the status-quo. The problem of systemic crisis was therefore not only that production would falter or investment decline, but that hopes would be dashed, and that the idea of harmony would give way to deep disappointment and a loss of faith, thereby seeding despair, resentment, and antipathy.

It is in the context of this inevitable reckoning that we can understand Polanyi, Keynes, and Carr's emphasis on the urgent need to manage these degenerative effects, a task to be undertaken through a collective rendering of what Jeremy Bentham termed the "Agenda" and the "Non-Agenda" of government. ${ }^{79}$ Today's

\footnotetext{
74. Ibid., 55.

75. Ibid., 81.

76. Ibid., 80 .

77. Ibid., 81.

78. Keynes, "The End of Laissez-faire," 48.

79. Ibid., 55.
} 
political economy consigns such adjustments to the realm of economic management. But the theorists of the interwar period were clear that such efforts to restore harmony demand much more than countercyclical measures-they require a sensitivity to the psychological, cultural, and social perils that inevitably accompany economic upheaval, and an explicit rendering of shared purpose and the public good.

Carr was certainly the most forceful in arguing that any rendering of what is properly held in common demanded a recognition of and reckoning with power. Liberalism, Carr argued, must face the inescapable element of human interest, and the value of his analysis lay in his positioning of the disruptions and dislocations of political economy in terms of the liberal model's failure to recognize and accommodate power. In the place of an analysis of power, the doctrine of the harmony of interests offered appeals to reason, law, and the knowledge of experts-all of which came to be understood by the disaffected as the means by which the privileged maintained their dominance. Assertions of the inevitable harmony between individuals, social classes, and nations appeared to the disaffected worker of this period as but "bitter mockery." ${ }^{\circ 0}$ In Carr's view, the "inferior status and insignificant stake" of the worker were reinforced and multiplied by an economic doctrine that erased both the struggling worker and the relations of power to which the worker was subjected. ${ }^{81}$ Grievance was piled upon grievance.

Yet, Carr also allowed that a too-often-overlooked moral element was at work in the interplay of domestic social forces; the exercise of organizational power alone will convince neither the embittered worker nor the self-satisfied factory owner to join in a common project. This moral element involved "a certain measure of common feeling as to what is just and reasonable in their mutual relations, a spirit of give-and-take and even of potential self-sacrifice, so that a basis, however imperfect, exists for discussing demands on grounds of justice recognized by both." ${ }^{2}$ While Carr maintained that the moral element of international relations was "embryonic" at best, he also recognized that within nations morality is essential to cultivating the public trust, so necessary for a shared rendering of the public good. ${ }^{83}$

For Polanyi, this kind of rendering is essential in good times as well as bad: the need for government is not reserved for periods of evident crisis, nor are the aims of intervention primarily economic improvement, though certainly improvement

80. Carr, The Twenty Years' Crisis, 81.

81. Ibid., 81.

82. Ibid., 220.

83. Carr, The Twenty Years' Crisis, 220. 
can be a means to an end-that end being the constructive adjustment of society to ceaseless change. Unmanaged economic progress will just as easily produce devastation as prosperity; economic improvement can swiftly turn things to ruin. Given the inevitability of change, the choice of "degenerative" versus "constructive" effects is a matter of managing the rate of change-not necessarily in managing the direction of the change itself. ${ }^{84}$ Government's role in economic life "consists often in altering the rate of change, speeding it up or slowing it down as the case may be" in order to give "the dispossessed" time to adjust themselves to changed conditions. ${ }^{85}$

Keynes similarly emphasizes that any organization of political economy is always only temporary; ${ }^{86}$ economic progress is fleeting and episodic. ${ }^{87}$ There is no returning to the conditions of a previous age: "the clock cannot be set back." ${ }^{88} \mathrm{~A}$ "plan to meet the problems of fifty years ago, based on a misunderstanding of what someone said a hundred years ago" 89 will only serve to strain the new structure, overwhelming "not only you and your guarantees, but your institutions, and the existing Order of your society." ${ }^{90}$ What must be addressed in any re-visioning of the public good is "the deeper economic tendencies which are to govern the future" justice and economic stability." 92 Crucially, the distinction between public and private-the determination of what is properly held in common—cannot be "settle[d] on abstract grounds"; it must always be distinguished "afresh." ${ }^{\text {" Hardly a radical }}$ democrat, Keynes argued that such moral and political discernment is "the chief task of economists," ${ }^{\prime 94}$ though he also understood that economic ideas must be paired with "the agency of collective action": ${ }^{95}$ it is the "companion task of politics to devise forms of government within a democracy which shall be capable of accomplishing the [government's] Agenda." ${ }^{\text {'6 }}$

84. Polanyi, The Great Transformation, 39.

85. Ibid., 39.

86. Keynes, The Economic Consequences, 3.

87. Ibid., 11.

88. Ibid., 37.

89. Keynes, "The End of Laissez-faire," 58.

90. Keynes, The Economic Consequences, 37.

91. Ibid., 37.

92. John Maynard Keynes, “Am I a Liberal?” in The Essential Keynes, ed. Robert Skidelsky (London: Penguin, 2015), 64.

93. Keynes, "The End of Laissez-faire," 55.

94. Ibid., 55.

95. Ibid., 59 .

96. Ibid., 55-56. 
Each in their own way, Polanyi, Keynes, and Carr stressed the need for a collective response to the disintegrating forces of liberalism. But they also doubted the capacity for a society under severe social strain to act collectively in keeping with a shared sense of what must be held in common. Tragically, as Keynes argued, it is "the agency of collective action" ${ }^{\prime 97}$ that is most corroded by the disintegrating forces of liberalism - unraveling not only the "delicate order" of liberal society but also the means by which that order might be restored. The penultimate legacy of liberalism - which equated the sum of private advantages with the public good, allowing "the public good to rest on 'the natural effort of every individual to better his own condition" "98 — was a collapse of the public's capacity "to determine what the State ought to take upon itself to direct by the public wisdom, and what it ought to leave, with as little interference as possible, to individual exertion." 99

The justification for such a stark conclusion about the power of what amounts to an entire metaphysics corresponds closely to the lingering moral authority and power that liberalism represents, a power that remains despite the collapse of "economic Utopia." ${ }^{100}$ What seems to have preoccupied Keynes more than the fiction of the doctrine itself was its "lasting hold over the conduct of public affairs." ${ }^{101}$ In Keynes's characterization, this hold was affective and reactive, as evidenced by the way that the exercise of public power "provokes such passionate suspicions in many upright breasts."102 These suspicions led to a compromised, perhaps irremediably damaged public trust, already so dangerously undermined by humiliation, insult, and mockery. His biographer Robert Skidelsky was correct to insist upon Keynes's philosophical imagination, for it was moral sentiment, and a host of psychological attachments, not argumentation, that so strenuously prohibits discrimination between the "Agenda" and the "Non-Agenda." 103 As Keynes so memorably put it, "to suggest social action for the public good to the City of London is like discussing the Origin of the Species with a bishop sixty years ago."104

Laissez-faire's lasting legacy was not the success of its economic program but the erasure of the public trust from politics, with catastrophic consequences. The

97. Keynes, “The End of Laissez-faire," 59.

98. Ibid., 42.

99. Ibid., 55.

100. Keynes, The Economic Consequences, 10.

101. Keynes, "The End of Laissez-faire," 53.

102. Keynes, "The End of Laissez-faire," 44.

103. Robert Skidelsky, Keynes: Economist, Philosopher, Statesman (New York: Penguin, 2005); and Robert Skidelsky, Keynes: Return of the Master (New York: Public Affairs).

104. Keynes, "The End of Laissez-faire," 54. 
warning signaled by Keynes in the years before the onset of the Second World War was that absent a re-articulation of the public good, the "lethargic monster" of laissez-faire would rule on. ${ }^{105} \mathrm{He}$ made clear the corresponding impact on the public trust: "Malthus's Devil is a terrible devil because he undermines our faith in the real value of our social purposes ..." ${ }^{106}$ The results would be predictably destructive: issues like German reparations would continue to be regarded by the public as a matter of theology, not of politics, ${ }^{107}$ and the interests of a few powerful states would be treated as the public good of an international society unconcerned with festering national problems. Anticipating the catastrophe of the war to come, Keynes turned his attention to "the unsettlement of the minds of the laboring classes" that emerged out of the collapse of the hopes of liberal internationalism. ${ }^{108}$ As the gap between promises and deliverables widened, the average worker would be made to reckon with the "tarnished" idol of laissez-faire: "we grow more doubtful whether it is he who will lead us into paradise by the hand." ${ }^{109}$ Keynes saw clearly that a range of emotions and states of mind, from lethargy to "mad despair" and "nervous instability of hysteria" 110 followed the "depression of the standard of life" and the onset of hunger. "Men will not always die quietly," he memorably warned. ${ }^{111}$ "But who can say how much is endurable, or in what direction men will seek at last to escape from their misfortunes?"112

\section{Deadlock and the Lure of Fascism}

Movements for social protection in the first decades of the last century are often remembered as democratic accommodations that required organizational power but also a wide degree of public trust in a shared national project. ${ }^{113}$ But what is sometimes forgotten is that the "Agenda" of the last century was consolidated following two devastating world wars. Indeed, measured by the sheer scale of political

105. Ibid., 55.

106. John Maynard Keynes, The Collected Writings of John Maynard Keynes, Vol. XIX (Cambridge: Cambridge University Press, 1981), 121-122.

107. Keynes, The Economic Consequences, 230.

108. Ibid., 232.

109. Keynes, "The End of Laissez-faire," 54.

110. Keynes, The Economic Consequences, 228.

111. Ibid., 228.

112. Ibid., 251.

113. These efforts are often contrasted with the failure of such movements in our own time. See Nancy Fraser, "A triple movement? Parsing the politics of crisis after Polanyi," New Left Review 81 (2013), 121. 
crisis, loss of life, and physical destruction, the early twentieth-century countermovement to re-embed economies in societies was nothing short of a failure that ended in fascism and organized violence on an industrial scale. This was a catastrophe that Polanyi anticipated and that Keynes and Carr imagined in their analysis of the dark power of unacknowledged grief and unreconciled embitterment. In the final analysis, the interwar theorists were concerned not with successful movements but with the cultural and political unraveling that follows a prolonged period of deadlock of social forces. They were all acutely aware of the dangerous potentials that accumulate in liberal societies when the social and psychological strains on democracy are ignored, unleashed by a collapse of the public trust.

Polanyi was particularly preoccupied with the "perilous deadlock" that arose from the "deep-seated institutional strain" of the interwar period; this strain was exacerbated by contending parties divided by social class. ${ }^{114}$ His analysis began with the insight that in the "emergency" conditions of the interwar period during which the "market system proved unreliable to the point of almost collapse," "routine" divergences of economic interest between employers and employees that "normally end in compromise," instead "took on an ominous character"; both labor and capital "invest[ed] such clashes with grave consequences to the community"; positions hardened, suspicions intensified, and "normal" methods gave way to "abnormal" ones. ${ }^{115}$ This clash of interests also paralyzed "legislative and executive bodies" captured by these forces. Absent institutions capable of "forming the communal will, the direction of public policy and the enactment of long-term programs at home and abroad," "both the economic and political systems were threatened by complete paralysis." 116

In his essay "Fascism and Marxism," Polanyi traced the disruption that followed from this paralysis back not to the particular economic interests of contending parties, but rather to the metaphysical clash of incompatible organizing principles:

Democracy and Capitalism, i.e., the existing political and economic system, have reached a deadlock, because they have become the instruments of two different classes of opposing interests. But the threat of disruption comes not from these opposing interests. It comes from the deadlock. This distinction is vital. The forces springing into action in order to avoid the deadlock

114. Polanyi, The Great Transformation, 140.

115. Ibid., 243.

116. Ibid., 244. 
are infinitely stronger than the forces of the opposing interests which cause the deadlock. Incidentally, this accounts for the cataclysmic vehemence of the social upheavals of our times. ${ }^{117}$

What resulted from this deadlocked double-movement is a "social and cultural catastrophe"118 - and not merely an economic one. Polanyi's distinction acknowledged the limits of defining dislocation or "exploitation" in "strictly economic terms." ${ }^{\prime 19}$ At stake in any process of undirected change"120 is not only material well-being or "a purely monetary definition of interests," 121 but what Polanyi called "the substance, human and economic, physical and moral" of the dispossessed. ${ }^{122}$

In suggesting that "a social calamity is primarily cultural, not an economic phenomenon that can be measured by income figures or population statistics," ${ }^{123}$ Polanyi pointed to the ways in which an "economistic prejudice" can obscure our "social vision"124_blinding those who set the government's "Agenda" to the way that rapid change accompanied by institutional deadlock can be felt as "cultural degradation" or "cultural loss," a loss of "self-respect." ${ }^{25}$ We forget that "economic motives per se are notoriously much less effective with most people than so-called emotional ones." ${ }^{\prime 26}$ Polanyi's conclusion is decisive: "purely economic matters such as affect want-satisfaction are incomparably less relevant to class behavior than questions of social recognition." ${ }^{27}$ Therefore, in considering the plight of the "ordinary man," 128 he noted "the immediate cause of his undoing is not for that reason economic, it lies in the lethal injury to the institution in which his social existence is embodied." 129

Polanyi's insistence that the disruptive "forces springing to action" in response to deadlock cannot be reduced to "opposing interests"130 is a valuable corrective

117. Karl Polanyi, Economy and Society: Selected Writings (Cambridge: Cambridge: Polity, 2018 [1934]), 134.

118. Polanyi, The Great Transformation, 169.

119. Ibid., 166.

120. Ibid., 35 .

121. Ibid., 162.

122. Ibid., 164.

123. Ibid., 164.

124. Ibid., 166.

125. Ibid., 165.

126. Ibid., 228.

127. Ibid., 160.

128. Carr, The Twenty Years' Crisis, 145.

129. Polanyi, The Great Transformation, 164.

130. Polanyi, Economy and Society, 134. 
to the economism prevalent in contemporary policy debates, a corrective which should incorporate all those psychosocial accompaniments of political-economic disorder: grief, resentment, mockery, betrayal, anger, and hatred, as well as demands for "social recognition" that include (but also exceed) economic motives, and which embody anxieties that concern social standing, rank, status, and security. ${ }^{131}$ Polanyi added a new sentiment, perhaps the most primal, to this volatile mix: in conditions of "complete paralysis," "fear would grip the people, and leadership would be thrust upon those who offered an easy way out at whatever ultimate price." ${ }^{132}$ Economic and sociocultural explanations for the rising tide of far-right populism need not be posed as distinct alternatives.

Psychological forces, then, are not unmitigated effects of economic crisis so much as they constitute a powerful and primary driver of social upheaval. For Polanyi, the "fascist solution"133 does not begin as a political movement at all, ${ }^{134}$ but first appears as "frequently vague and ambiguous" symptoms of an "impersonal crisis" - an "almost instantaneous emotional reaction"135 that, "like socialism, was rooted in a market society that refused to function." ${ }^{36}$ The aim of fascism "transcends the political and economic framework. It is social. It puts a political religion into the service of a degenerative process. In its rise it excludes only a very few emotions from its orchestra ..."137

Evidence of the social dynamics of fascism are found in the variety of "organized forms" taken by this virus, ${ }^{138}$ a disease fed by fear that progresses in a situation of deadlock. Lacking strength as a political movement in its critical early stages, the "fascist crisis" 139 that precipitated the Second World War exploited existing vulnerabilities and dispositions - a willingness to accept "irrationalistic philosophies, racialist aesthetics, anticapitalistic demagogy, heterodox currency views, criticism of the party system, widespread disparagement of the "regime," 140 as well as attacks against a free press. The issues "transcended the economic sphere" and the "general transformation" that such emotions unleashed was "of a distinctively social kind ... radiating into almost every field of human activity whether political or economic,

131. Polanyi, The Great Transformation, 160.

132. Ibid., 244.

133. Ibid., 244.

134. Ibid., 246.

135. Ibid., 247.

136. Ibid., 248.

137. Ibid., 249.

138. Polanyi, Economy and Society, 108.

139. Polanyi, The Great Transformation, 140.

140. Ibid., 246. 
cultural, philosophic, artistic, or religious." ${ }^{141}$ If for Walter Benjamin fascism marked the moment when politics becomes a practice of aesthetics, ${ }^{142}$ for Polanyi it amounted to something like a political religion forced into the service of a "degenerative process," one that was underway long before the most ominous warning signs appeared. ${ }^{143}$

Fascism trafficked in emotions that were capable of moving the masses very abruptly, but energies were rarely directed at symptoms of a specific affliction or a crisis. "There were no accepted criteria of fascism, nor did it possess conventional tenets. Yet one significant feature of all these forms was the abruptness with which they appeared and faded out again, only to burst forth with violence after an indefinite period of latency." 144 The concept of latency is significant, marking the steady accumulation of psychosocial potentials beneath the surface of seemingly wellfunctioning liberal societies. These potentials are difficult to dissipate, particularly in a society where the public trust has eroded: "once the common mind has received the impress of an acute danger, fear remains latent, as long as its ultimate cause is not removed." 145

What makes all these latent sentiments so dangerous is their potential to be harnessed, not to build a movement, but to ensure receptivity and acquiescence to the fascist solution to "the impasse reached by liberal capitalism." Fascism resolved the deadlock through "the abolition of the Democratic 'political sphere' altogether,"146 "a reform of market economy achieved at the price of the extirpation of all democratic institutions . . ."147 Polanyi well understood fascism's independence from "popular movement" politics. "Though usually aiming at a mass following, its potential strength was reckoned not by the numbers of its adherents but by the influence of the persons in high position whose good will the fascist leaders possessed, and whose influence in the community could be counted upon to shelter them from the consequences of an abortive revolt, thus taking the risks out of revolution." 148 What so clearly marked the "fascist situation" was the ease with which "minute fascist forces would brush aside what seemed until then the overwhelming strength of democratic governments, parties, trade unions . . . the bulwarks

141. Polanyi, The Great Transformation, 248.

142. Walter Benjamin, Illuminations: Essays and Reflections (New York: Schocken Books), 241.

143. Polanyi, The Great Transformation, 249.

144. Ibid., 247.

145. Ibid., 199.

146. Polanyi, The Great Transformation, 105.

147. Ibid., 245.

148. Ibid., 246. 
of democracy and constitutional liberties were stormed and their defenses found wanting ..."149 As Benjamin also recognized, a political revolution was never on offer-existing property structures would be preserved as long as the masses were given the means to express themselves: "the violation of the masses, whom Fascism, with its Führer cult, forces to their knees, has its counterpart in the violation of an apparatus which is pressed into the production of ritual values." 150

European fascism's unique amalgam of psychosocial and cultural dispositions - all the regimes of ignorance, confusion, deception, and humiliation-took years to gain a foothold in the political imaginations of people reeling from the collapse of the gold standard, the end of empire, the mismanagement of reparations and all the rest, severely compromising the public's trust in decency, reciprocity, redistribution, moral probity, cross-national respect and generosity, and political forgiveness. In this context we can understand Polanyi's characterization of fascism as a "move"151 — a "social force"152 that draws on latent psychosocial potentials and cultural amalgamations-rather than as a mass movement. The strains and tensions that accompanied institutional deadlock "remained latent as long as [the] world economy continued to function." But with the collapse of "market civilization," "the stress within the nations [was] finally released." ${ }^{53}$ In sum, Polanyi offers a sobering diagnosis of the accumulating dangers facing a society in which the give and take of the double movement has been arrested by institutional paralysis and the collapse of the public trust. Absent a shared vision of the public purpose that would mitigate the inevitable dislocations of liberalism, sentiments of discord will only accumulate beneath a harmonious surface of exchange; in conditions of deadlock, these latent sentiments become acute symptoms, taking a variety of organized cultural forms, appearing and disappearing, until they finally congeal to produce, quite suddenly, an illiberal and undemocratic political form. Fascism thus remained "an ever-given political possibility." 154

\section{Contemporary Perils}

Polanyi and his contemporaries recognized that the origins of the crisis of the interwar period lay in individuals' most basic understandings of the person and

149. Ibid., 247.

150. Benjamin, Illuminations, 241

151. Polanyi, The Great Transformation, 245.

152. Ibid., 247.

153. Ibid., 228.

154. Ibid., 247. 
community. They stressed that the "delicate order" of liberalism is sustained not only by functioning markets and government institutions, but by the integrity of individual and collective dispositions, and the propensity of beliefs, feelings, and even illusions to strengthen those dispositions, lending meaning to a broad array of life experiences. An elaborate psychosocial and cultural fabric is an irremediable part of the defining character of the political times. This fabric can be compromised by hopes dashed, anxieties suffered, and demands for recognition thwarted-experiences that so often accompany and exacerbate the dislocations of open economies and liberal societies.

Despite the many profound transformations of economy and society that distinguish today's world from the world of nearly a century ago, there are nevertheless several unique points of convergence between the interwar period and our own that suggest avenues of inquiry for political economists seeking to grapple with the relationship between economic and social change, cultural upheaval, and the transfiguration of these events into political organization and adaptation. Most immediately, the interwar theorists point to the perils of measuring the well-being of any society by economic factors alone. The limits of this approach have certainly been borne out-both in the United States, where general improvements in output and employment prior to the COVID-19 pandemic were accompanied by the steady advance of inequality and the intensification of political polarization, and across Europe, where low unemployment and steady GDP growth in the Netherlands, Denmark, Austria, and other countries coincided with the electoral success of right-wing populist parties. As one commentator notes, economic forecasting fails to account for a lingering sense that "at the microlevel of society, systemic disintegration and the resulting structural indeterminacy continue apace." ${ }^{55}$

Economism still prevails today in so many contemporary public policy fora, and political economists would do well to recall Polanyi's argument that liberalism shares with Marxism a considerable blind spot when it comes to understanding the full range of human motives underlying calls for "social protection." 156 A public good narrowly tailored to overcoming economic crisis and alleviating material hardship will inevitably leave a residue of grievance in those domains of life that bear on time-honored social anxieties in the context of the "new economy," anxieties that will only fester in the cultural cauldrons of today's supercharged (social) media environments. Today, as during the interwar period, people have little reason to believe "that economic needs would automatically fill [the] void and make 
life appear livable under whatever conditions." 157 A government "Agenda" whose success is measured by improvement in macroeconomic indicators, but one blinded to lingering anxieties of rank, status, and culture, will necessarily fail to capture the social and psychological character of today's most insidious grievance politics. This lasting insight of Polanyi's goes some way towards explaining the shortcomings of trade adjustment assistance, the limits of fiscal and monetary measures implemented in the United States and Europe during the Great Recession, and the lingering social effects of austerity. Vital bonds of mutual obligation and trust are further weakened by the failure to hold elites and institutions to account in times of crisis, fueling widespread resentment and outrage.

Policymakers should recall the ambitious and urgent task for government noted by the interwar theorists: the necessity of managing the rate of change; the need to control and to direct economic forces to shared ends; and the imperative to accommodate demands for many kinds of social and political recognition. Economic policymaking is therefore but one component of an "Agenda" that must be attentive to the need for cultural revitalization and social investment.

Yet, the search for collective remedies is complicated by the fact that repressive institutions and attitudes are not easily separable from those that progressives might want to preserve or retain-such as the rural farm community, the manufacturing town, and the vibrant downtown. The unsettling of even the most coercive and dehumanizing institutions-among them, racism, patriarchy, and empirecan be experienced as a "loss" by those people whose existence is inseparable from the enforcement of material, social, as well as symbolic hierarchies.

The already-difficult work of political analysis is further imperiled by the decay of trust so evident in the contemporary political environment, a decay that is linked to the proliferation of new cultural dynamics which propagate fear, antipathy, and resentment-dynamics that are amplified by media technologies, from cable news to social media platforms. In the United States and also in much of Europe, a wide variety of powerful cultural assemblages have formed in the wake of growing economic inequalities and against the background of deteriorating social structures. These assemblages draw on latent pools of distrust and disaffection that have accumulated over at least a generation, a period corresponding to the increasing dysfunction of deadlocked government institutions. Into this vacuum "'culture' comes in [to play], which seems to grow all the more important for social order 
as the institutions become less responsive and are overrun by the normalizing effects of social intercourse" in everyday life. ${ }^{158}$

Organized and amplified "cultural-symbolic" expressions of grievance ${ }^{159}$ draw in not only those who have been materially impacted by deindustrialization and global trade, but also millions whose politics are shaped by deepening sentiments of grievance and resentment, many of them stoked in fragmented digital domains. Feelings of "bitter mockery"160 and "acute danger"161 are reinforced through narratives that induce sentiments of said social loss and cultural decline. Today most especially one can appreciate the feelings of attachment and the dispositional orientations rooted not in knowledge, certainly not in self-knowledge, and scarcely in faith tradition, party platform, or political ideology. Forces far more complex are at work, drawing on broad cultural patterns of embedded indignation, racism, xenophobia, and bigotry that have surfaced alongside, not apart from, the pressures and incentive structures of global capitalism.

\section{Conclusion}

Given these old and emerging challenges to the "delicate order" of liberalism, policy changes will be insufficient absent a political renewal that can reconstitute the public trust through a confrontation with the widening and deepening cultural currents of antipathy, anger, and distrust that are convulsing in much of America and Europe today. ${ }^{162}$ The political agenda before us must go beyond warnings about the resurgence of fascism. Recent interventions on this subject ${ }^{163}$ should be read in the context of Polanyi's warning that fascism "is merely the most recent and most virulent outburst of the anti-democratic virus which was inherent in industrial capitalism from the start." ${ }^{164}$ Framed in this manner, the challenge today consists in wresting control of new cultural forms that have coalesced around a range of no-longer-latent psychosocial sentiments.

158. Streeck, How Will Capitalism End?, 38.

159. Ibid., 209.

160. Carr, The Twenty Years' Crisis, 81.

161. Polanyi, The Great Transformation, 199.

162. See Snyder, The Road to Unfreedom.

163. See Madeline Albright, Fascism: A Warning (New York: HarperCollins, 2018); Jason Stanley, How Fascism Works: The Politics of Us and Them (New York: Random House, 2018); and Timothy Snyder, On Tyranny: Twenty Lessons from the Twentieth Century (New York: Tim Duggan Books, 2017).

164. Polanyi, The Great Transformation, 108. 
The task for political economy is therefore three-fold. First, the field must question the persistence of myths and grievances related to perceived societal ills and injuries in rapidly transforming economies. This will require an examination of the numerous and interpenetrating sources of distrust, disaffection, and resentment that impede a re-visioning of the public good at a critically important turning point in the history of global capitalism. ${ }^{165}$ Second, as public trust further erodes, political economists should investigate how psychosocial responses, as well as the new political cultures they are helping to effect, do more than negate the potential for collective action. As grievances give way to organized expressions of exclusion and blame, they enact a political quest of their own, one oriented around building a collective purpose along racial and ethno-nationalist lines. Third, political economists must grapple with the increased pace of social and economic change and attend to the ways that expectations in relation to this change are managed. A society's capacity to adapt to shifting circumstances depends on the strength of the public trust. Any political renewal must therefore be of a cultural character. What is required are organized, proactive responses capable of challenging the hegemony of anxiety-ridden sentiments bearing on experiences of loss and socioeconomic insecurity. As part of this task, societies must expand appeals to community in ways that can integrate sub- and cross-national groupings.

Understanding the psychosocial and cultural dynamics that have eroded the public trust is only the first step in the urgent work of political renewal. Restoring the public trust and advancing a more ambitious and imaginative public purpose will require both political will and institutional means. Absent a new "Agenda" capable of arresting the disintegration unleashed by the metaphysical clash of democracy and capitalism, the latent antagonisms of psychology and culture require only the force of events to "burst forth" in ways scarcely imagined heretofore. ${ }^{166}$

165. Investigations of accumulating distrust can proceed from a variety of starting points, including the reexamination of classical liberal theorists. Paul Dragos Aligica et al. find in the classical assumptions of liberalism resources to explicitly address the problem of connecting individuals' subjective values with the domains of institutions and social order. See Paul Dragos Aligica, Peter J. Boettke, and Vlad Tarko, Public Governance and the Classical-Liberal Perspective: Political Economy Foundations (Oxford: Oxford University Press, 2019).

166. Polanyi, The Great Transformation, 247. 
Scott G. Nelson is Associate Professor in the Department of Political Science at Virginia Tech. He is the author of Sovereignty and the Limits of the Liberal Imagination (Routledge, 2010), and co-editor of the Ashgate Research Companion to Modern Theory, Modern Power, World Politics: Critical Investigations (Ashgate, 2016). He can be reached at scnelson@vt.edu.

Joel T. Shelton is Assistant Professor of Political Science \& Policy Studies at Elon University. His research focuses on the political economy of governance, development, and statecraft in historical and theoretical perspective. He is the author of Conditionality and the Ambitions of Governance: Social Transformation in Southeastern Europe (Palgrave Macmillan, 2015), and co-author of Research and Writing in International Relations, $3^{\text {rd }}$ ed (Routledge, 2020). He can be reached at jshelton10@elon.edu. 